AperTO - Archivio Istituzionale Open Access dell'Università di Torino

Growth performance of common catfish (Ameiurus melas Raf.) fingerlings fed Tenebrio molitor meal diet

This is a pre print version of the following article:

Original Citation:

Availability:

This version is available http://hdl.handle.net/2318/1529845

since 2019-12-22T16:36:05Z

Published version:

DOI:10.3920/JIFF2014.0006

Terms of use:

Open Access

Anyone can freely access the full text of works made available as "Open Access". Works made available under a Creative Commons license can be used according to the terms and conditions of said license. Use of all other works requires consent of the right holder (author or publisher) if not exempted from copyright protection by the applicable law. 


\title{
Growth performance of common catfish (Ameiurus melas Raf.) fingerlings fed mealworm
}

\section{(Tenebrio molitor) diet}

\author{
A. Roncarati ${ }^{1 *}$, L. Gasco ${ }^{2}$, G. Parisi ${ }^{3}$ and G. Terova ${ }^{4}$ \\ ${ }^{1}$ University of Camerino, School of Biosciences and Veterinary Medicine, Viale Circonvallazione 94/96, 62024 Matelica, \\ Italy; ${ }^{2}$ University of Turin, Department of Agricultural, Forest, and Food Sciences (DISAFA), Largo Paolo Braccini 2, \\ 10095 Grugliasco, Italy; ${ }^{3}$ University of Florence, Section of Animal Sciences, Department of Agri-Food Production and \\ Environmental Sciences, Via delle Cascine 5, 50144 Florence, Italy; ${ }^{4}$ University of Insubria, Department of Biotechnology \\ and Life Sciences, Via J.H. Dunant 3, 21100 Varese, Italy; alessandra.roncarati@unicam.it
}

Received: 27 June 2014 / Accepted: 9 March 2015

() 2015 Wageningen Academic Publishers

RESEARCH ARTICLE

\begin{abstract}
A pre-fattening trial was performed to evaluate the effect of replacement of fishmeal (FM) with insect meal (IM; Tenebrio molitor) on growth performance and survival rate of common catfish (Ameiurus melas). Fingerlings of A. melas (mean body weight $0.248 \pm 0.07 \mathrm{~g}$ ) were randomly distributed over 4 indoor tanks of $2 \mathrm{~m}^{3}$ at a density of $2,000 \mathrm{fish} / \mathrm{tank}$, and kept at a temperature of $23-25^{\circ} \mathrm{C}$ in two separated recirculating aquaculture systems. Fish were divided into two groups (two tanks per group): FM and IM. Fish of the FM group were fed with a control diet (51.6\% protein and $18.1 \%$ lipid), whereas those of the IM group received a diet (50.8\% protein and $22.1 \%$ lipid) in which $50 \%$ of FM was substituted with IM. Chemical parameters (moisture, crude protein, total lipids, ether extract, and ash) and fatty acid profile of the two feeds is reported. The feeding trial lasted 90 days and fish were weighed at the beginning of the trial and then on monthly basis. Growth performance was good in both groups. However, fish of the IM group reached a final mean body weight $(4.2 \pm 0.6 \mathrm{~g})$ significantly lower $(P<0.01)$ than that of the FM group $(5.13 \pm 0.7 \mathrm{~g})$. The survival rate of FM group $(79 \%)$ was higher than that of IM $(70 \%)$, too. In conclusion, the results of this study demonstrated that the diet with insect meal was able to sustain growth in catfish fingerlings but fish fed with FM performed better than those fed with IM.
\end{abstract}

Keywords: aquaculture, common catfish, insect meal, growth performance, survival rate, Tenebrio molitor

\section{Introduction}

In black bullhead or common catfish (Ameiurus melas, Rafinesque) culture, the pre-fattening phase is commonly carried out in ponds where fingerlings are fed on balanced diets until they reach the weight of $10-12 \mathrm{~g}$ and the length of $7-10 \mathrm{~cm}$. The success of this phase depends on many factors, including the absence of predators, and environmental parameters such as temperature and water quality (Bardach et al., 1972; Melotti et al., 1993). Carrying out the early rearing phase in hatchery has been suggested as a way to improve fish growth and to avoid herpes virus infection. This virus caused a drastic reduction in Italian catfish production in the 1990s. Usually, contagious herpes virus affects only catfish less than four months old and the most favourable temperatures for herpes virus infection are $28-30{ }^{\circ} \mathrm{C}$, which are common during summer in Italy. Therefore, to avoid potential carriers (survivors) or infected fry, the growth of common catfish can only be achieved using water at temperatures below $27^{\circ} \mathrm{C}\left(23-24^{\circ} \mathrm{C}\right.$ ) (Alborali et al., 1996; Gobbo et al., 2010; Parisi et al., 2014; Roncarati et al., 2014).

Feed is one of the principal factors affecting fingerling production; commercial feeds are formulated as complete diets and contain a balance of all nutrients necessary to meet common catfish dietary requirements (National Research Council, 2011). The inclusion of vegetable ingredients, as a substitute for the more expensive fishmeal, is a common practice in catfish feed production. However, the nutritional 
imbalance or the presence of anti-nutritional factors in vegetable meals can reduce fish growth (Gatlin et al., 2007).

One potential source of nutrients and a good candidate for replacing fishmeal in aquafeeds is insect meal (Barroso et al., 2014; Sánchez-Muros et al., 2014; Vantomme, 2015). Research on the use of different insect meals in fish diet has produced encouraging results. In catfish species, the use of maggot meal (Musca domestica) in Clarias gariepinus fingerlings diet (Fasakin et al., 2003; Olele, 2011) or the inclusion of termite meal (Macrotermes subhyalinus; winged reproductive caste) as a protein source in mud catfish (Heterobranchus longifilis) diet (Sogbesan and Ugwumba, 2008), had a positive effect on growth and feed utilisation efficiency. Indeed, Fasakin et al. (2003), found that growth performance and nutrient utilisation (feed gain ratio and protein intake) of C. gariepinus fingerlings fed on diets in which $40 \%$ of fishmeal was replaced by either defatted oven dried or defatted sun-dried maggot meal, were not significantly different from those of fish fed on a fish mealbased diet. However, the processing methods of defattening and drying influenced nutrient availability, palatability and utilisation of the maggot meal and in general, catfish performed better when fed diets containing defatted than full-fat maggot meal (Fasakin et al., 2003).

The authors of another study (Sogbesan and Ugwumba, 2008) found the highest mean weight gain and specific growth rate in fingerlings of Heterobranchus longifilis fed on a diet in which $50 \%$ of fish meal was substituted by termite (M. subhyalinus, winged reproductive caste) meal. Five experimental diets, in which termite meal was used to replace fishmeal at 0, 25, 50, 75 and $100 \%$ inclusion levels, were tested in this study. The lowest feed conversion ratio and the highest protein efficiency ratio were recorded in fish fed $50 \%$ termite meal inclusion diet. The significantly lower level of crude protein in the termite meal $(46.3 \%)$ in comparison to that in fishmeal (71.5\%), suggests that the difference found in protein efficiency in this study was due to the quality rather than to the quantity of protein (Sogbesan and Ugwumba, 2008).

In view of these considerations, we performed a prefattening phase trial to evaluate the effect of partial replacement of fishmeal (FM) with Tenebrio molitor meal on the growth performance and survival rate of common catfish (A. melas) fingerlings.

\section{Materials and methods}

Fingerlings of $A$. melas of 28-31 days of age, collected in a spawning pond, were randomly distributed over 4 indoor tanks of $2 \mathrm{~m}^{3}$ at a density of 2,000 fish/tank and kept at a temperature of $23-25^{\circ} \mathrm{C}$ in two separate recirculating aquaculture systems (one circuit system per diet).
The initial mean body weight of fish was $0.248 \pm 0.07 \mathrm{~g}$. Fish were divided in two groups (two tanks per group): FM and insect meal (IM; T. molitor), differing for the feed. Fish of the FM group were fed with a control diet (51.6\% FM protein and $18.1 \%$ lipid), whereas those of the IM group received a diet with a similar protein content $(50.8 \%)$ in which $50 \%$ of FM was substituted with IM.

To manufacture each feed, meals were finely ground into powder and then mixed with water, oil, vitamin-mineral premix and other ingredients to produce a stiff dough. The two doughs were pelleted by pressing them through a sieve of $4 \mathrm{~mm}$ holes in an experimental feed mill and reduced to crumble size (200-500 $\mu \mathrm{m})$. Diets were dried in a thermostat (equipped with probes) at $40{ }^{\circ} \mathrm{C}$ until the moisture level decreased below $8 \%$ and then stored at $-20^{\circ} \mathrm{C}$ in black bags.

The ingredients, chemical composition, and fatty acid profile of the two feeds are shown in Table 1 and 2, respectively. The chemical analysis of three samples from each feed was performed according to the Association of Official Analytical Chemists procedure (AOAC, 1990). Total lipid content was determined using the procedure described by Folch et al. (1957). After determining total lipid content, fatty acids were converted to methyl esters following the method described by Christopherson and Glass (1969). The separation of fatty acids was carried out using a GC 3800 gas chromatograph (Varian Strumentazione, Cernusco sul Naviglio, Italy) with a WP-4 Shimadzu integration

Table 1. Composition and chemical parameters (mean \pm standard deviation) of the two experimental diets provided to catfish fingerlings during the trial.

\begin{tabular}{|c|c|c|}
\hline & Fish meal (FM) & Insect meal (IM) \\
\hline \multicolumn{3}{|l|}{ Ingredients (g/kg) } \\
\hline FM & 238.4 & 119.2 \\
\hline Insect meal & - & 119.2 \\
\hline Soybean meal & 190.7 & 190.7 \\
\hline Corn gluten & 47.7 & 47.7 \\
\hline Fish oil & 167.1 & 167.1 \\
\hline Vitamin and mineral premix & 50 & 50 \\
\hline Cellulose & 306 & 306 \\
\hline \multicolumn{3}{|c|}{ Chemical parameters ( $\%$ of feed $)^{1}$} \\
\hline Moisture & $7.66 \pm 0.9$ & $6.75 \pm 0.6$ \\
\hline Crude protein & $51.64 \pm 0.4$ & $50.83 \pm 0.8$ \\
\hline Total lipids & $18.10 \pm 0.7 \mathrm{~B}$ & $22.09 \pm 0.7 \mathrm{~A}$ \\
\hline Ether extract & $12.63 \pm 0.5$ & $11.43 \pm 0.8$ \\
\hline Ash & $9.97 \pm 0.2 \mathrm{a}$ & $8.89 \pm 0.3 b$ \\
\hline
\end{tabular}


Table 2. Fatty acid profile (mean \pm standard deviation) of the two diets provided to catfish fingerlings during the trial (\% of total fatty acids). ${ }^{1}$

\begin{tabular}{|c|c|c|}
\hline Fatty acid ${ }^{2}$ & Fish meal (FM) & Insect meal (IM) \\
\hline C 11:0 & $0.91 \pm 0.04 \mathrm{a}$ & $0.42 \pm 0.02 b$ \\
\hline C 12:0 & $0.00 \pm 0.00$ & $0.00 \pm 0.00$ \\
\hline C $14: 0$ & $8.98 \pm 0.03 \mathrm{~A}$ & $5.79 \pm 0.08 \mathrm{~B}$ \\
\hline C $15: 0$ & $1.41 \pm 0.02 \mathrm{~A}$ & $0.70 \pm 0.03 \mathrm{~B}$ \\
\hline C $16: 0$ & $20.66 \pm 1.14 \mathrm{~A}$ & $18.87 \pm 1.02$ B \\
\hline C $17: 0$ & $1.22 \pm 0.05$ & $1.04 \pm 0.04$ \\
\hline C $18: 0$ & $4.20 \pm 0.05 a$ & $3.45 \pm 0.02 b$ \\
\hline C 20:0 & $0.00 \pm 0.00$ & $0.00 \pm 0.00$ \\
\hline C 21:0 & $2.33 \pm 0.02 b$ & $3.28 \pm 0.04 \mathrm{a}$ \\
\hline C $24: 0$ & $0.34 \pm 0.03 b$ & $0.48 \pm 0.01 a$ \\
\hline Total SFA & $40.05 \pm 0.35 \mathrm{~A}$ & $34.03 \pm 0.31 \mathrm{~B}$ \\
\hline C $14: 1$ & $0.00 \pm 0.00$ & $0.00 \pm 0.00$ \\
\hline C $15: 1$ & $0.00 \pm 0.00$ & $0.00 \pm 0.00$ \\
\hline C $16: 1$ & $7.80 \pm 0.52 \mathrm{~A}$ & $3.80 \pm 0.03 \mathrm{~B}$ \\
\hline C $17: 1$ & $1.33 \pm 0.06 \mathrm{a}$ & $0.99 \pm 0.04 b$ \\
\hline C 18:1 trans & $0.00 \pm 0.00$ & $0.00 \pm 0.00$ \\
\hline C $18: 1$ cis & $15.60 \pm 0.72 \mathrm{~B}$ & $20.73 \pm 0.40 \mathrm{~A}$ \\
\hline C 20:1 & $2.39 \pm 0.04 \mathrm{a}$ & $1.28 \pm 0.02 b$ \\
\hline C 22:1 & $0.00 \pm 0.00$ & $0.00 \pm 0.00$ \\
\hline C $24: 1$ & $0.00 \pm 0.00$ & $0.00 \pm 0.00$ \\
\hline Total MUFA & $27.12 \pm 0.27$ & $26.80 \pm 0.13$ \\
\hline C $18: 2 \mathrm{n}-6$ trans & $1.51 \pm 0.05 a$ & $0.78 \pm 0.05 b$ \\
\hline C $18: 2 n-6$ cis & $5.02 \pm 0.06 \mathrm{~B}$ & $20.39 \pm 0.08 \mathrm{~A}$ \\
\hline C 18:3n-6 & $0.00 \pm 0.00$ & $0.00 \pm 0.00$ \\
\hline C 20:2n-6 & $0.00 \pm 0.00$ & $0.00 \pm 0.00$ \\
\hline C 20:4 n-6 & $2.99 \pm 0.04 \mathrm{~A}$ & $1.31 \pm 0.03 \mathrm{~B}$ \\
\hline C 20:3 n-6 & $0.00 \pm 0.00$ & $0.00 \pm 0.00$ \\
\hline Total n-6 & $9.52 \pm 0.16 \mathrm{~B}$ & $22.48 \pm 0.03 \mathrm{~A}$ \\
\hline C 18:3n-3 & $1.47 \pm 0.03 b$ & $1.55 \pm 0.03 a$ \\
\hline C 18:4 n-3 & $0.00 \pm 0.00$ & $0.00 \pm 0.00$ \\
\hline C 20:3 n-3 & $0.00 \pm 0.00$ & $0.12 \pm 0.04$ \\
\hline C 20:5 n-3 & $10.14 \pm 0.09 \mathrm{~A}$ & $5.08 \pm 0.07 \mathrm{~B}$ \\
\hline C 22:5 n-3 & $0.92 \pm 0.04 a$ & $0.52 \pm 0.06 b$ \\
\hline C 22:6 n-3 & $7.21 \pm 0.07 \mathrm{~A}$ & $4.13 \pm 0.03 \mathrm{~B}$ \\
\hline Total n-3 & $19.74 \pm 0.04 \mathrm{~A}$ & $11.40 \pm 0.03 \mathrm{~B}$ \\
\hline Total PUFA & $29.26 \pm 0.03 B$ & $33.88 \pm 0.03 \mathrm{~A}$ \\
\hline$n-6 / n-3$ & $0.48 \pm 0.05 B$ & $2.00 \pm 0.04 \mathrm{~A}$ \\
\hline C $22: 2$ & $0.00 \pm 0.00$ & $0.12 \pm 0.01$ \\
\hline Others & $3.57 \pm 0.09 \mathrm{~B}$ & $5.17 \pm 0.08 \mathrm{~A}$ \\
\hline
\end{tabular}

${ }^{1}$ Means are the result of analysis performed in triplicate. Different letters mean significant differences between FM and IM: A, B: $P<0.01$; $a$, b: $P<0.05$.

2 MUFA = monounsaturated fatty acids; PUFA = polyunsaturated fatty acids; SFA = saturated fatty acid. system (Shimadzu Corporation, Tokyo, Japan), which was equipped with a Supelco SP 2340 capillary column $(30 \mathrm{~m}$ $\times 0.25 \mathrm{~mm}$ i.d.; $0.25 \mu \mathrm{m}$ film thickness; Supelco, Bellefonte, Pennsylvania, USA) and a flame ionisation detector.

The feeding trial lasted 90 days and fish were weighed at the beginning of the trial and then on monthly basis. The amount of feed provided was based on the fish weight at the first day of a period. The daily amount of FM feed provided to the fish was: $531 \mathrm{~g}$ for the first 30 days, 714 $\mathrm{g}$ for the second month, and 1,350 g for the last 30 days, whereas the daily amount of IM was: $315.5,643$, and 1,125 g, respectively. Fish were fed by means of automatic feeders (12 h day). Feed in excess was daily removed by using a siphon hose system.

During the trial, the main water physicochemical parameters (temperature, dissolved oxygen and $\mathrm{pH}$ ) of the two recirculating systems were recorded on a weekly basis. Total ammonia nitrogen, nitrites and nitrates were analysed following American Public Health Association standard methods (Clesceri et al., 1989). The levels of all these parameters resulted similar in the two recirculating systems, during the trial.

At the end of the trial, final body weight was measured and used to calculate the specific growth rate (SGR) with the following formula:

$\mathrm{SGR}=\frac{\ln \mathrm{Wf}-\ln \mathrm{Wi}}{\mathrm{t}} \times 100$

Where Wf is the final weight (g), Wi is the initial weight (g), and $\mathrm{t}$ is growth time (days). The The food conversion rate (FCR) was calculated as follows:

$\mathrm{FCR}=\frac{\text { total } \mathrm{kg} \text { feed fed }}{\text { total } \mathrm{kg} \text { of fish weight gain }}$

And the survival rate as follows:

Survival rate $=\frac{\text { final number of fish }}{\text { initial number of fish }} \times 100$

In order to detect differences in body weight, SGR, FCR, and survival rate data ( $\mathrm{n}=30 \mathrm{fish})$ were analysed by oneway analysis of variance (ANOVA) using the SAS General Model procedure (SAS Institute, 1988). The means were separated by a Student Newmann Keuls test. Differences were considered significant at $P<0.05$ and $P<0.01$.

\section{Results}

The meal of T. molitor (yellow mealworm) used in this trial contained $51.9 \%$ of crude proteins, $23.6 \%$ of lipids, and $4.7 \%$ of ash (on dry weight basis). These values result in agreement with those reported in literature for T. molitor meal (Aguilar-Miranda et al., 2002; Finke, 2002; Makkar et al., 2014; Oonincx and De Boer, 2012). 
The chemical composition of the two feeds showed significant differences $(P<0.01)$ in the lipid content, which was $18.10 \%$ in FM feed and $22.09 \%$ in IM feed (Table 1). This was due to the insect larvae meal, which was a full fat meal containing $23.6 \%$ of fat. The most abundant saturated fatty acid (SFA) in IM was C16:0 (3.43 g/100 g dry matter). As for the mono unsaturated fatty acids, IM was poor in C16:1 and rich in C18:1 cis (0.4 and 7.58 g/100 g dry matter, respectively). The content of C18:2 n- 6 was $6.97 \mathrm{~g} / 100 \mathrm{~g}$ dry matter whereas $\mathrm{C} 20: 5 \mathrm{n}-3$ and $\mathrm{C} 22: 6 \mathrm{n}-3$ were not detected.

The partial substitution of FM with IM led to noticeable changes in the diets with significant decreases $(P<0.01)$ of SFA (from $40.05 \%$ in FM to $34.03 \%$ in IM) and n-3 fatty acids (from $19.74 \%$ in FM to $11.40 \%$ in IM), and a notable increase $(P<0.01)$ of $\mathrm{n}-6$ fatty acids and polyunsaturated fatty acids. The $\mathrm{n}-6 / \mathrm{n}-3$ ratio was much higher $(P<0.01)$ in IM in comparison to FM feed (Table 2).

During the trial, the main water physicochemical parameters (Table 3) were within the range considered optimal for catfish (Melotti and Roncarati, 2013).

The main growth performance data are reported in Table 4. Fish of the IM group reached a final mean body weight of $4.18 \pm 0.6 \mathrm{~g}$, which was significantly lower $(P<0.01)$ than that reached by the FM group $(5.13 \pm 0.7 \mathrm{~g})$. The highest SGR was recorded at 30 days of experiment in both groups $(\mathrm{FM}=5.17 \% / \mathrm{d} ; \mathrm{IM}=3.18 \% / \mathrm{d})$. At 60 days, SGR of the IM group was significantly higher $(3.16 \% / d)$ than that of the

Table 3. Main water physicochemical parameters ( $\mathrm{DO}=$ dissolved oxygen; $\mathrm{TAN}=$ total nitrogen ammonia; $\mathrm{NO}_{2}=$ nitrites; $\mathrm{NO}_{3}=$ nitrates; mean \pm standard deviation) recorded weekly (FM = fish meal; IM = insect meal).

\begin{tabular}{|c|c|c|c|c|c|c|}
\hline \multirow[t]{2}{*}{ Day } & \multicolumn{2}{|c|}{ Temperature $\left({ }^{\circ} \mathrm{C}\right)$} & \multicolumn{2}{|l|}{ DO (mg/l) } & \multicolumn{2}{|l|}{$\mathrm{pH}$} \\
\hline & $\mathrm{FM}$ & IM & $\mathrm{FM}$ & IM & FM & IM \\
\hline 1 & $17.9 \pm 0.2$ & $17.8 \pm 0.2$ & $7.52 \pm 0.1$ & $7.53 \pm 0.2$ & $7.82 \pm 0.2$ & $7.81 \pm 0.2$ \\
\hline 7 & $18.2 \pm 0.1$ & $18.5 \pm 0.1$ & $7.63 \pm 0.5$ & $7.59 \pm 0.4$ & $7.84 \pm 0.1$ & $7.83 \pm 0.1$ \\
\hline 14 & $18.9 \pm 0.2$ & $18.8 \pm 0.2$ & $7.61 \pm 0.6$ & $7.62 \pm 0.3$ & $7.85 \pm 0.3$ & $7.84 \pm 0.2$ \\
\hline 21 & $19.7 \pm 0.2$ & $19.8 \pm 0.3$ & $7.75 \pm 0.6$ & $7.74 \pm 0.6$ & $7.82 \pm 0.1$ & $7.81 \pm 0.2$ \\
\hline 30 & $20.3 \pm 0.4$ & $20.2 \pm 0.2$ & $7.74 \pm 0.2$ & $7.78 \pm 0.5$ & $7.87 \pm 0.3$ & $7.87 \pm 0.1$ \\
\hline 37 & $20.7 \pm 0.3$ & $20.8 \pm 0.3$ & $7.81 \pm 0.4$ & $7.80 \pm 0.6$ & $7.89 \pm 0.2$ & $7.88 \pm 0.2$ \\
\hline 44 & $20.9 \pm 0.5$ & $20.6 \pm 0.4$ & $7.79 \pm 0.5$ & $7.81 \pm 0.6$ & $7.86 \pm 0.1$ & $7.87 \pm 0.3$ \\
\hline 51 & $21.3 \pm 0.4$ & $21.2 \pm 0.3$ & $7.78 \pm 0.9$ & $7.80 \pm 0.7$ & $7.87 \pm 0.2$ & $7.86 \pm 0.2$ \\
\hline 60 & $21.9 \pm 0.5$ & $22.0 \pm 0.2$ & $7.82 \pm 0.9$ & $7.81 \pm 0.8$ & $7.90 \pm 0.3$ & $7.89 \pm 0.2$ \\
\hline 67 & $22.1 \pm 0.3$ & $22.1 \pm 0.3$ & $7.82 \pm 0.6$ & $7.82 \pm 0.8$ & $7.94 \pm 0.2$ & $7.91 \pm 0.3$ \\
\hline 74 & $22.2 \pm 0.3$ & $22.0 \pm 0.3$ & $7.86 \pm 0.5$ & $7.84 \pm 0.8$ & $7.93 \pm 0.3$ & $7.91 \pm 0.3$ \\
\hline 81 & $22.1 \pm 0.2$ & $22.2 \pm 0.2$ & $7.85 \pm 0.9$ & $7.86 \pm 0.9$ & $7.95 \pm 0.4$ & $7.93 \pm 0.4$ \\
\hline 90 & $22.0 \pm 0.6$ & $22.3 \pm 0.1$ & $7.88 \pm 0.8$ & $7.86 \pm 0.8$ & $7.95 \pm 0.2$ & $7.96 \pm 0.3$ \\
\hline \multirow[t]{2}{*}{ Day } & TAN (mg/l) & & \multicolumn{2}{|l|}{$\mathrm{NO}_{2}(\mathrm{mg} / \mathrm{l})$} & \multicolumn{2}{|l|}{$\mathrm{NO}_{3}(\mathrm{mg} / \mathrm{l})$} \\
\hline & $\mathrm{FM}$ & IM & $\mathrm{FM}$ & IM & $\mathrm{FM}$ & IM \\
\hline 1 & $0.21 \pm 0.01$ & $0.21 \pm 0.01$ & $0.021 \pm 0.001$ & $0.022 \pm 0.001$ & $2.00 \pm 0.03$ & $2.01 \pm 0.03$ \\
\hline 7 & $0.21 \pm 0.02$ & $0.22 \pm 0.02$ & $0.023 \pm 0.001$ & $0.022 \pm 0.002$ & $2.01 \pm 0.04$ & $2.02 \pm 0.04$ \\
\hline 14 & $0.21 \pm 0.02$ & $0.21 \pm 0.03$ & $0.021 \pm 0.001$ & $0.023 \pm 0.002$ & $2.02 \pm 0.03$ & $2.04 \pm 0.03$ \\
\hline 21 & $0.21 \pm 0.01$ & $0.20 \pm 0.03$ & $0.021 \pm 0.002$ & $0.024 \pm 0.001$ & $2.01 \pm 0.02$ & $2.01 \pm 0.04$ \\
\hline 30 & $0.22 \pm 0.01$ & $0.23 \pm 0.01$ & $0.022 \pm 0.003$ & $0.024 \pm 0.003$ & $2.02 \pm 0.02$ & $2.03 \pm 0.05$ \\
\hline 37 & $0.23 \pm 0.02$ & $0.23 \pm 0.02$ & $0.024 \pm 0.001$ & $0.023 \pm 0.002$ & $2.05 \pm 0.04$ & $2.04 \pm 0.03$ \\
\hline 44 & $0.22 \pm 0.02$ & $0.24 \pm 0.02$ & $0.021 \pm 0.003$ & $0.022 \pm 0.002$ & $2.06 \pm 0.02$ & $2.03 \pm 0.04$ \\
\hline 51 & $0.24 \pm 0.02$ & $0.23 \pm 0.03$ & $0.024 \pm 0.002$ & $0.023 \pm 0.002$ & $2.07 \pm 0.03$ & $2.03 \pm 0.02$ \\
\hline 60 & $0.24 \pm 0.02$ & $0.21 \pm 0.03$ & $0.026 \pm 0.003$ & $0.024 \pm 0.002$ & $2.08 \pm 0.02$ & $2.04 \pm 0.03$ \\
\hline 67 & $0.22 \pm 0.01$ & $0.21 \pm 0.04$ & $0.025 \pm 0.003$ & $0.025 \pm 0.002$ & $2.09 \pm 0.04$ & $2.07 \pm 0.02$ \\
\hline 74 & $0.23 \pm 0.02$ & $0.22 \pm 0.03$ & $0.026 \pm 0.004$ & $0.024 \pm 0.001$ & $2.09 \pm 0.03$ & $2.08 \pm 0.03$ \\
\hline 81 & $0.24 \pm 0.02$ & $0.22 \pm 0.03$ & $0.025 \pm 0.002$ & $0.025 \pm 0.002$ & $2.08 \pm 0.04$ & $2.11 \pm 0.03$ \\
\hline 90 & $0.23 \pm 0.02$ & $0.23 \pm 0.02$ & $0.027 \pm 0.003$ & $0.027 \pm 0.002$ & $2.11 \pm 0.05$ & $2.12 \pm 0.04$ \\
\hline
\end{tabular}


FM one $(2.79 \% / d ; P<0.05)$. At the end of the trial, the SGR decreased in both groups, without showing significant differences $(\mathrm{FM}=2.50 \% / \mathrm{d} ; \mathrm{IM}=2.64 \% / \mathrm{d})$. The survival rate of FM group (79\%) was higher than that of IM one (70\%; $P<0.01)$. FCR ranged from 3.8 (FM) to 4.1 (IM) without showing significant differences.

\section{Discussion and conclusions}

This study investigated the use of $T$. molitor meal in the common catfish diet during a very early phase of fish rearing cycle. We used a water recirculation system able to control water quality suitable for catfish culture in tanks (Martins et al., 2010). The main water physicochemical parameters were maintained within the range considered optimal for Ictalurid species (Melotti and Roncarati, 2013).

In the last ten years, different studies have been performed to assess the potential of different insect meals as an alternative source of animal protein in the feeds for freshwater and marine fish species (for a review see Sánchez-Muros et al., 2014). Feeding experiments performed in vivo with diets based on insect meal in Clarias anguillaris (Achionye-Nzeh and Ngwudo, 2003), C. gariepinus (Alegbeleye et al., 2012; Aniebo et al., 2011; Fasakin et al., 2003, Ng et al., 2001), Orcorhychus mykiss (Sealey et al., 2011; St-Hilaire et al., 2007), Oreochromis niloticus (Ogunji et al., 2008), and Psetta maxima (Kroeckel et al., 2012) have demonstrated that, in general, percentages of substitution higher than $30 \%$ decreased the growth depending on the fish and insect species.

Indeed, in the study of Alegbeleye et al. (2012), the replacement of $25 \%$ of fishmeal by meal from variegated grasshopper (Zonocerus variegatus L.) adult in the diet of C. gariepinus led to an improved growth rate and nutrient utilisation, in comparison to the fish of the control group that were fed on a fishmeal based diet. However, growth was negatively influenced in C. gariepinus fingerlings when the inclusion of $Z$. variegatus was increased above $50 \%$, with a significant decrease in nutritive indices and at $100 \%$ inclusion, the growth performance declined significantly.

Similar results were obtained in the study of $\mathrm{Ng}$ et al. (2001) conducted in African catfish (C. gariepinus) that were fed on diets in which fishmeal component was progressively substituted at 20, 40, 60, 80 and 100\% with mealworm (T. molitor). A $20 \%$ substitution resulted in growth performance and feed utilisation efficiency similar to that obtained with the control diet that was prepared without any worm meal. However, a reduction in growth performance, feed intake, and protein utilisation were observed in catfish that were fed with high levels of mealworm meal or solely mealworms.
The results of our study do not differ very much from those of Alegbeleye et al. (2012) and Ng et al. (2001). We tested the T. molitor meal in the feeding of 28-31 days old common catfish (A. melas) fingerlings. In this phase, the most important parameters of a rearing technique are survival and growth whereas feed conversion is less important (Appelbaum and Van Damme, 1988). In our trial, catfish fed on a diet in which $50 \%$ of fishmeal was substituted with mealworm meal, reached a final mean body weight significantly lower than that of fish fed on a fishmeal based diet. Specific growth rate showed a good value during the first month but then it decreased in both groups at the end of the second month, remaining at the end of the trial, slightly higher in catfish fed on IM diet in comparison to those fed on FM diet.

The chitin content, digestibility, amino acid balance, and fatty acid composition, appear to prevent the inclusion of insects in fish diets at levels higher than 30\%. However, in the study of Kroeckel et al. (2012), juvenile turbot (P. maxima) accepted diets containing from 17 to $76 \%$ defatted black fly soldier (Hermetia illucens) larvae meal as a replacement of fishmeal. Nevertheless, higher than 33\% inclusion rates of Hermetia meal decreased the acceptance of the diet and this resulted in reduced feed intake and lower fish growth performance. The presence of chitin might have reduced feed intake and nutrient availability and therefore reduced fish growth performance and nutrient utilisation (Kroeckel et al., 2012).

In rainbow trout O. mykiss, St-Hilaire et al. (2007) determined that the replacement of $25 \%$ of the fishmeal and $38 \%$ of the fish oil components of a commercial diet with black soldier fly (H. illucens) pre-pupae meal had no effect on the feed conversion ratio. However, given that $H$. illucens diets were low in fish oil, which is as known rich in polyunsaturated fatty acids, rainbow trout had reduced levels of n-3 fatty acids in their fillets. Nevertheless, a study of Sealey et al. (2011) with black soldier flies indicated that the fatty acid profiles of insects most likely reflect the fatty acid composition of the insects' food. Therefore, the polyunsaturated fatty acid content could be increased by supplementing the insect's diet with fish offal during the last month of development. Indeed, no significant difference was observed by Sealey et al. (2011) in a blind comparison of fish that were fed the control diet containing fishmeal compared to fish that were fed normal $H$. illucens or fish offal-enriched $H$. illucens pre-pupae diets.

The fatty acid profile of the T. molitor meal that we used in our trial was in accordance with the profile found in previous studies (Aguilar-Miranda et al., 2002; Finke, 2002; Tzampa-Sosa et al., 2014). The n-6/n-3 ratio of yellow mealworm meal was 25 (Gasco et al., 2014). According to Fontaneto et al. (2011), in the fatty acid profile of edible insects differing for the habitat (terrestrial vs aquatic), the 
proportions of saturated and polyunsaturated fatty acids are similar but terrestrial insects have significantly higher levels of n-6 fatty acids.

Indeed, for most insect species, more than half of the fatty acids are unsaturated (for a review see Finke and Oonincx, 2014). The most prevalent unsaturated fatty acids found in insects are palmitoleic (C16:1), oleic (C18:1), linoleic (C18:2), and linolenic (C18:3) acids. The main saturated fatty acids found in insects are palmitic acid (C16:0) and stearic acid (C18:0), and like in most other land animals, palmitic is normally present in larger quantities than stearic acid. Polyunsaturated fatty acid content has been reported to vary between $0.4 \%$ and $52.4 \%$ (Finke and Oonincx, 2014). In yellow mealworm larvae, $\mathrm{C} 18: 1$ seems to be the most prevalent fatty acid, but $\mathrm{C} 18: 2$ and $\mathrm{C} 18: 3$ constitute 25.5 and $0.3 \%$ of the total fatty acids, respectively (AguilarMiranda et al., 2002).

The survival rate observed in our experiment was significantly higher in catfish fed on IM diet (79\%) than in those fed on the FM one (70\%). These percentages are in line with the survival rates of 70-72.5\% reported by Fasakin et al. (2003) in clariid catfish (C. gariepinus) fingerlings fed on diets containing either full fat sun-dried or full fat oven dried housefly maggot meal. However, in the same study, the survival rate of fish fed on defatted sun-dried or defatted oven-dried maggot meal was 87.5 and $90 \%$, respectively. Similar survival rates (73-76\%) were also observed by Ogunji et al. (2007) in tilapia (O. niloticus) fingerlings fed on diets formulated with housefly (M. domestica) maggot meal inclusion levels of $45 \%$ and $68 \%$. Nevertheless, a survival rate of $100 \%$ was obtained in this study at a level of $25 \%$ maggot meal (replacing $34 \%$ fishmeal) in the diet.

It has been reported (for a review see Finke and Oonicx, 2014) that macro-mineral levels in insect meals are lower than in fishmeal, in particular calcium and phosphorus, and this could have affected the growth of catfish fingerlings in our study. Most species of insects contain a low quantity of calcium (typically less than $0.3 \%$ of dry matter) because with very few exceptions, insects as invertebrates do not have a mineralised skeleton (Barker et al., 1998; Finke, $2002,2013)$. The exoskeleton of most insects is primarily composed of protein and chitin, whereas some insects such as black soldier fly have a mineralised exoskeleton in which calcium and other minerals are incorporated into the cuticle (Finke, 2013). The phosphorus content of insects is much higher than calcium levels. In mealworm larvae, calcium : phosphorus ratio is 1:16.9, and unlike plant based phytate phosphorus, the phosphorus in insects is likely to be readily available (Finke, 2002; Makkar et al., 2014). For these reasons, feeding fish with mealworms exclusively can lead to Ca deficiency and body malformations. However, in our study, the inclusion of $50 \%$ of T. molitor meal in substitution of FM did not cause any adverse effect on body conformation. Therefore, it can be assumed that our diets met the dietary macro-mineral requirements of common catfish.

$\mathrm{n}-6 \mathrm{n}-6$. In conclusion, the results of our study demonstrated that the insect meal (T. molitor) based diet was able to sustain growth in catfish (A. melas) fingerlings, but fish fed on fishmeal performed better than those fed on mealworm meal. Further research is needed on the nutritional potential of T. molitor as a new raw ingredient for common catfish feeds and to determine the optimal level of mealworm meal to be included without impairing fish growth performances.

\section{Acknowledgements}

This work has been supported by Fondazione Cariplo grant no. 2014-0550, project title 'Insect Bioconversion: from vegetable waste to Protein production for fish Feed (InBioProFeed)'. The authors would like to thank Gaobeidian Shannong Biology CO., Ltd (Gaobeidian, Hebei province, China P.R.) for providing Tenebrio molitor meal.

\section{References}

Achionye-Nzeh, C.G. and Ngwudo, O.S., 2003. Growth response of Clarias anguillaris fingerlings fed larvae of Musca domestica and soyabean diet in the laboratory. Bioscience Research Communications 15: 221-223.

Aguilar-Miranda, E.D., López, M.G., Escamilla-Santana, C. and Barba de la Rosa, A.P., 2002. Characteristics of maize flour tortilla supplemented with ground Tenebrio molitor larvae. Journal of Agriculture and Food Chemistry 50: 192-195.

Alborali, L., Bovo, G., Lavazza, A., Cappellaro, H. and Guadagnini, P.F., 1996. Isolation of an herpesvirus in breeding catfish (Ictalurus melas). Bulletin European Association Fish Pathology 16: 134-137.

Alegbeleye, W.O., Obasa, S.O., Olude, O.O., Otubu, K. and Jimoh, W., 2012. Preliminary evaluation of the nutritive value of the variegated grasshopper (Zonocerus variegatus L.) for African catfish Clarias gariepinus (Burchell. 1822) fingerlings. Aquaculture Research 43: 412-420.

Aniebo, A.O., Odukwe, C.A., Ebenebe, C.I., Ajuogu, P.K., Owen, O.J. and Onu, P.N., 2011. Effect of housefly larvae (Musca domestica) meal on the carcass and sensory qualities of the mud catfish (Clarias gariepinus). Advances in Food and Energy and Security 1: 24-28.

Appelbaum, S. and Van Damme, P., 1988. The feasibility of using exclusively dry diet for rearing of Israeli Clarias gariepinus (Burchell) larvae and fry. Journal of Applied Ichthyology 4: 105-110.

Association of Official Analytical Chemists (AOAC), 1990. Meat and meat products. In: Official methods of analysis international $\left(17^{\text {th }}\right.$ Ed.). AOAC, Rockville, MD, USA, pp. 931-948.

Bardach, J.E., Ryther, J.H. and McLarnay, W.O., 1972. Aquaculture the farming and husbandry of freshwater and marine organisms. John Wiley \& Sons, Inc., New York, NY, USA, 868 pp.

Barker, D., Fitzpatrick, M.P. and Dierenfeld, E.S., 1998. Nutrient composition of selected whole invertebrates. Zoo Biology 17: 123-134. 
Barroso, F.G., De Haro, C., Sánchez-Muros, M.-J., Venegas, E., Martínez-Sánchez, A. and Pérez-Bañón, C., 2014. The potential of various insect species for use as food for fish. Aquaculture 422423: 193-201.

Christopherson, S.W. and Glass, R.L., 1969. Preparation of milk methyl esters by alcoholysis in an essentially non-alcoholic solution. Journal of Dairy Science 52: 1289-1290.

Clesceri, L.S., Greenberg, A.E. and Trussell, R.R. (eds.), 1989. Standard methods for the examination of water and wastewater (1 $17^{\text {th }} \mathrm{Ed}$.). American Water Works Association, Denver, CO, USA, American Public Health Association, Washington, DC, USA.

Fasakin, E.A., Balogun, A.M. and Ajayi, O.O., 2003. Evaluation of full-fat and defatted maggot meals in the feeding of clariid catfish Clarias gariepinus fingerlings. Aquaculture Research 34: 733-738.

Finke, M.D., 2002. Complete nutrient composition of commercially raised invertebrates used as food for insectivores. Zoo Biology 21: 269-285.

Finke, M.D., 2013. Complete nutrient content of four species of feeder insects. Zoo Biology 32: 27-36.

Finke, M.D. and Oonincx, D.G.A.B., 2014. Insects as food for insectivores. In: Morales-Ramos, J.A., Guadalupe Rojas, M. and Shapiro-Ilan, D.I. (eds.) Mass production of beneficial organisms. Invertebrates and entomopathogens. Academic Press, Philadelphia, PA, USA, pp 583-617.

Folch, J., Lees, M. and Sloane-Stanley, G.H., 1957. A simple method for the isolation and purification of total lipids from animal tissues. Journal of Biological Chemistry 60: 497-509.

Fontaneto, D., Tommaseo-Ponzetta, M., Galli, C., Risé, P., Glew, R.H. and Paoletti, M.G. 2011. Differences in fatty acid composition between aquatic and terrestrial insects used as food in human nutrition. Ecology of Food and Nutrition 50: 351-367.

Gasco, L., Gai, F., Piccolo, G., Rotolo, L., Lussiana, C., Molla, P. and Chatzifotis, S., 2014. Substitution of fish meal by Tenebrio molitor meal in the diet of Dicentrarchus labrax juveniles. In: Abstract book Conference Insects to Feed the World, May 14-17, 2014, Wageningen, the Netherlands, $70 \mathrm{pp}$.

Gatlin, D.M., Barrows, F.T., Brown, P., Dabrowski, K., Gaylord, T.G., Hardy, R.W., Herman, E., Hu, G., Krogdahl, Å., Nelson, R., Overturf, K., Rust, M., Sealey, W., Skonberg, D., Souza, E.J., Stone, D., Wilson, R. and Wurtele, E., 2007. Expanding the utilization of sustainable plant products in aquafeeds: a review. Aquaculture Research 38: 551-579.

Gobbo, F., Cappellozza, E., Pastore, M.R. and Bovo, G., 2010. Susceptibility of black bullhead Ameiurus melas to a panel of ranavirus isolates. Diseases of Aquatic Organisms 90: 167-174.

Kroeckel, S., Harjes, A.G.E., Roth, I., Katz, H., Wuertz, S., Susenbeth, A. and Schulz, C., 2012. When a turbot catches a fly: evaluation of a pre-pupae meal of the black soldier fly (Hermetia illucens) as FM substitute - growth performance and chitin degradation in juvenile turbot (Psetta maxima). Aquaculture 364-365: 345-352.

Makkar, H.P.S., Tran, G., Huezé, V. and Ankers, P., 2014. State-ofthe-art on use of insects as animal feed. Animal Feed Science and Technology 197: 1-33.
Martins, C.I.M., Eding, E.H., Verdegem, M.C.J., Heinsbroek, L.T.N., Schneider, O., Blancheton, J.P., Roque d'Orbcastel, E. and Verreth, J.A.J., 2010. New developments in recirculating aquaculture systems in Europe: a perspective on environmental sustainability. Aquacultural Engineering 43: 83-93.

Melotti, P., Gennari, L. and Roncarati, A., 1993. Ictalurus and other introduced species: possibilities and prospects in Europe. In: Kestemont, P. and Billard, R. (eds.). Workshop on aquaculture of freshwater species (except salmonids). EAS special publication no. 20, Ghent, Belgium, pp. 19-20.

Melotti, P. and Roncarati, A., 2013. L'allevamento dei pesci gatto e dei ciprinidi. Il Divulgatore 1-2: 53-61.

National Research Council, 2011. Nutrient requirements of fish and shellfish. National Academy Press, Washington, DC, USA, 376 pp.

Ng, W.-K., Liew, F.-L., Ang, L.-P. and Wong, K.-W., 2001. Potential of mealworm (Tenebrio molitor) as an alternative protein source in practical diets for African catfish, Clarias gariepinus. Aquaculture Research 32 (Suppl. 1): 273-280.

Ogunji, J., Toor, R.-U.-A., Schulz, C. and Kloas, W., 2008. Growth performance, nutrient utilization of Nile tilapia Oreochromis niloticus fed housefly maggot meal (magmeal) diets. Turkish Journal of Fisheries and Aquatic Sciences 8: 141-147.

Ogunji, J.O., Nimptsch, J., Wiegand, C. and Schulz, C., 2007. Evaluation of the influence of housefly maggot meal (magmeal) diets on catalase, glutathioneS-transferase and glycogen concentration in the liver of Oreochromis niloticus fingerling. Comparative Biochemistry and Physiology A: Molecular \& Integrative Physiology 147: 942-947.

Olele, N.F., 2011. Comparative study on the use of natural and artificial based feeds for the culture of Clarias gariepinus fingerlings. ARPN Journal of Agricultural and Biological Science 6: 9-13.

Oonincx, D.G.A.B. and De Boer, I.J.M., 2012 Environmental impact of the production of mealworms as a protein source for humans - a life cycle assessment. PLoS ONE 7: e51145.

Parisi, G., Terova, G., Gasco, L., Piccolo, G., Roncarati, A., Moretti, V.M., Centoducati, G., Gatta, P.P. and Pais, A., 2014. Current status and future perspectives of Italian finfish aquaculture. Reviews in Fish Biology and Fisheries 24: 15-73.

Roncarati, A., Mordenti, O., Stocchi, L. and Melotti, P., 2014. Comparison of growth performance of 'Common catfish Ameiurus melas, Rafinesque 1820, reared in pond and in recirculating aquaculture system. Journal of Aquaculture Research and Development 5: 218.

Sánchez-Muros M.J., Barroso, F.G. and Manzano-Agugliaro, F., 2014. Insect meal as renewable source of food for animal feeding: a review. Journal of Cleaner Production 65: 16-27.

SAS Institute, 1988. SAS $/$ STAT guide for personal computers. Release 6.03 Edition. SAS Institute Inc., Cary, NC, USA.

Sealey, W.M., Gaylord, T.G., Barrows, F.T., Tomberlin, J.K., McGuire, M.A., Ross, C. and St-Hilaire, S., 2011. Sensory analysis of rainbow trout, Oncorhynchus mykiss, fed enriched black soldier fly prepupae, Hermetia illucens. Journal of World Aquaculture Society 42: 34-45. Sogbesan, A.O. and Ugwumba, A.A.A., 2008. Nutritional evaluation of termite (Macrotermes subhyalinus) meal as animal protein supplements in the diets of Heterobranchus longifilis (Valenciennes, 1840) fingerlings. Turkish Journal of Fisheries and Aquatic Sciences 8: 149-157. 
St-Hilaire, S., Sheppard, C., Tomberlin, J.K., Irving, S., Newton, L., McGuire, M.A., Mosley, E.E., Hardy, R.W. and Sealey, W., 2007. Fly prepupae as a feedstuff for rainbow trout, Oncorhynchus mykiss. Journal of World Aquaculture Society 38: 59-67.
Tzampa-Sosa, D.A., Yi, L., Van Valenberg, H.J.F., Van Boekel, M.A.J.S. and Lakemond, C.M.M., 2014. Insect lipid profile: aqueous versus organic solvent-based extraction methods. Food Research International 62: 1087-1094.

Vantomme, P., 2015. Way forward to bring insects in the human food chain. Journal of Insects as Food and Feed 2: \#\#\#-\#\#. 